\title{
The Reverse Side Effects of Mark to Market Accounting Exista and the Saga of Leveraged Paper Profits
}

Mixa, Mar Wolfgang; Bryant, Murray; Sigurjonsson, Olaf

Document Version

Accepted author manuscript

Published in:

International Journal of Critical Accounting

DOI:

10.1504/IJCA.2016.10002498

Publication date:

2016

License

Unspecified

Citation for published version (APA):

Mixa, M. W., Bryant, M., \& Sigurjonsson, O. (2016). The Reverse Side Effects of Mark to Market Accounting: Exista and the Saga of Leveraged Paper Profits. International Journal of Critical Accounting, 8(5/6), 463-477. https://doi.org/10.1504/IJCA.2016.10002498

Link to publication in CBS Research Portal

\section{General rights}

Copyright and moral rights for the publications made accessible in the public portal are retained by the authors and/or other copyright owners and it is a condition of accessing publications that users recognise and abide by the legal requirements associated with these rights.

Take down policy

If you believe that this document breaches copyright please contact us (research.lib@cbs.dk) providing details, and we will remove access to the work immediately and investigate your claim. 


\section{The Reverse Side Effects of Mark to Market Accounting: Exista and the Saga of Leveraged Paper Profits}

\section{Mar Wolfgang Mixa, Murray Bryant, and Olaf Sigurjonsson}

Journal article (Final published version)

GITE: The Reverse Side Effects of Mark to Market Accounting : Exista and the Saga of Leveraged Paper Profits. / Mixa, Mar Wolfgang; Bryant, Murray; Sigurjonsson, Olaf. In: International Journal of Critical Accounting, Vol. 8, No. 5/6, 2016, p. 463-477.

001: 10.1504/IJCA.2016.10002498

Uploaded to Research@CBS: January २०18 


\title{
The reverse side effects of mark to market accounting: Exista and the saga of leveraged paper profits
}

\section{Már Wolfgang Mixa*}

School of Business,

Reykjavik University,

Menntavegur 1 - 101 Reykjavík, Iceland

Email: marmixa@ru.is

*Corresponding author

\section{Murray Bryant}

Ivey,

The University of Western Ontario, Canada

Email: mbryant@rogers.com

\section{Throstur Olaf Sigurjonsson}

School of Business,

Reykjavik University, Iceland

and

INT,

Copenhagen Business School, Denmark

Email: throstur@ru.is

\begin{abstract}
We describe holding companies and their main roles. We follow up by describing the spectacular development of the investment company, Exista. We then discuss how the difference in fair value methods and equity methods may provide a false picture of the state of companies. This applies especially to different types of holding companies. Our paper shows an example of one that people generally perceived as being a financial company when in reality was more like an investment company, in this case a highly risky and leveraged one.
\end{abstract}

Keywords: investment companies; fair value accounting; mark to market accounting; Iceland; equity method.

Reference to this paper should be made as follows: Mixa, M.W., Bryant, M. and Sigurjonsson, T.O. (xxxx) 'The reverse side effects of mark to market accounting: Exista and the saga of leveraged paper profits', Int. J. Critical Accounting, Vol. X, No. Y, pp.000-000. 
Biographical notes: Már Wolfgang Mixa is an Assistant Professor at the School of Business, Reykjavik University. He holds a PhD from Reykjavik University, an MA in Corporate Finance from the University of Iceland, a BSBA in Finance and a BA in Philosophy from the University of Arizona. He worked for 15 years in the financial banking industry and was the main researcher regarding investments for the Parliamentary Special Investigation Commission looking into the causes and events that eventually lead to the fall of the Icelandic savings banks system in 2008.

Murray Bryant is a Professor Emeritus of Management Accounting and Control at the Ivey School of Business, Western University, London, Ontario. He holds a PhD from the University of Cincinnati, and is Chartered Accountant of Australia and New Zealand. He teaches Management accounting and control, as well as risk, accountability and governance, and has taught at several universities: Reykjavik University, Iceland, Rotterdam School of Management, the Netherlands, Monash University, Australia, and Johannes Kepler University, Austria. He writes many cases including Landsbanki hf: Where to From Here?

Throstur Olaf Sigurjonsson is an Associate Professor of Strategic Management at the School of Business, Reykjavik University in Iceland and the Copenhagen Business School (CBS) in Denmark. He holds a $\mathrm{PhD}$ from Copenhagen Business School (CBS) in Denmark. His research interests include issues of strategic management, strategic execution, corporate governance, privatisation and corporate restructuring.

This paper is a revised and expanded version of a paper entitled 'The role of a hedge fund: accounting, regulation and wrongdoing contributing to financial collapse' presented at International Conference of Critical Accounting, 'The Challenges and Future of the Accounting Profession', New York, 28-29 April 2016.

\section{Introduction}

A great deal has been written in recent years about the negative effects and possible abuses regarding the use of fair value measures, often known as mark-to-market accounting standards. Such accounting standards have been criticised, for example, for contributing to financial bubbles being formed and also exacerbating the downturn once they burst (Epstein and Henderson, 2009). Among the best known examples of such abuse is Enron, which used such accounting practices in various ways to paint a rosier view of the state of the company. This was by showing more profits than were in reality being created, and also covering up the inherent risks associated with its assets (McLean and Elkind, 2003), with such fair value accounting being substantially responsible for Enron's eventual demise (Benston, 2006). While Enron has been a much discussed subject regarding fair value measures, little thought has been given to other types of changes in accounting standards. An example would be where companies owning listed assets decide to use some other value measurements on listed assets, instead of using fair value measure accounting practices, where they are booked in accordance to market value. 
These above negative effects and complications deal with, to a great extent, how well investors and the general public can evaluate a company's financial health, both regarding their future income stream and inherent risk. This is a subject being scrutinised by auditors and risk managers (for example, rating agencies specialists), especially following debacles like Enron, but also many other financial companies within the financial industry, many of which seemed to be providing solid profits, only to become bankrupt or needing massive government aid following the financial crisis that started in 2007. Governance issues are intertwined in such matters, depending on what types of investors are investing in companies and the appropriateness of such investments for general investors.

We provide in this paper an example of a company that used mark-to-market accounting methods until early 2007 when it changed its methods regarding its two major holdings, booking their value instead at the current market price. The company, a major listed holding company, Exista, reported immense profits using mark-to-market accounting standards from its inception in 2001 until summer 2007, enabling Exista to reap major profits, since its investments not only increased consistently in value, but did so with the use of leveraged investing. From that point, however, the losses were enormous with most of Exista's assets, which were very few and all interrelated, falling in value and due to its use of leverage the losses were greater, in a similar fashion as the gains during the boom period. The level of such sudden losses, while visible by simple deductions clearly evident in Exista's balance sheet, bypassed a large amount of investors due to changes in Exista's accounting methods that took place during the first part of 2007. In other words, the leveraged profits of the rising value of Exista's assets were recorded on its net income statement and balance sheet, while the losses were mostly not.

Exista was enormously influential in creating the financial bubble. Exista and related parties caused $44 \%$ of the Icelandic pension fund system total losses related to the banking crash (Special Commission Pension Funds, 2012). When holding companies are made public, they usually must adhere to stringent rules and regulations, on par with other listed companies. It can be said that while such companies do not involve the same customer protection as mutual funds, their operations and disclosures must be transparent enough for investors to adequately assess the associated risks and rewards in investing in each company. Exista was publicly presented by its main owners as a financial company, owning financial assets. They asserted that it had a similar investment policy as Berkshire Hathaway (Morgunbladid, 2006). Exista was in reality, to some degree, like a private equity fund in the sense that it invested exclusively in the stock of Kaupthing, which was an investment bank, and companies related to or rumoured to be acquisition targets of Kaupthing. The leverage feature of Exista, financing on average more than half of its investments with borrowed money, throughout its existence made the 'financial company' look more like a hedge fund than a traditional investment holding company, which rarely finance their operations with borrowed money. The companies in which Exista invested their bulk of shares were also highly leveraged. These were either financial companies, which generally have only a small portion of their balance sheet as equity, or Bakkavor, a food production company that was highly leveraged, with a balance sheet consisting, to a large degree, of goodwill (Bakkavor Group, 2002).

In this paper we will describe holding companies and their role in general. We follow this by describing the spectacular development of Exista. We then discuss how the difference in fair value methods and equity methods may provide a false picture of the 
state of companies, especially ones that people generally perceive as being a financial company, when in reality it is an investment company. The high returns for a few years painted a picture showing patterns of a success story created largely by the use of leveraged investing, and even possible market manipulation, and that concealed to most investors the risk inherent within the company, despite it being very obvious. This, we believe, opened doors to abuse, especially in a country with a limited experience of financial issues.

\section{The role and details of holding companies}

Holding companies are quite common in financial services. They are entities that generally own a diversified portfolio of financial assets. Holding companies listed on public exchanges generally have a similar purpose for common investors as mutual funds. By investing in such companies a level of diversification is almost always achieved, albeit to differing degrees. There are generally four types of investment holding companies; mutual funds, private equity funds, hedge funds and holding companies. Mutual funds are widely used for pension plans and individual investments due to their consumer protection; holding companies usually own diversified assets but face less regulation, while private equity funds and hedge funds are generally only for accredited investors who can afford losing huge portions of their investments within such vehicles, often operating under limited regulation.

An ideal example of the benefits of diversification in holding companies lessening idiosyncratic risk is the McDonalds food chain. While its business is usually solid, its market value fell about $60 \%$ during the 'mad cow' disease scare in 2002-2003. An investor owning a share in McDonalds would have suffered heavy losses despite owning a share in a relatively stable corporation with world-wide operations. If McDonalds would be merely 1 of 20 companies within a holding company with a similar value as the other companies, its value within the portfolio would be $1 / 20$ or $5 \%$, assuming that the market value of the other holdings within the portfolio are similar, and the total losses only $3 \%$ ( $60 \%$ of the $5 \%$ holding within the portfolio). This diversification is similar to the benefits of owning shares in mutual funds, a common method of investing in financial securities that has a great deal of consumer protection.

The main general difference between holding companies and investment companies, often mutual funds, is that a holding company that is listed on public exchanges usually must adhere to the same laws and regulations as other companies listed on publicly traded exchanges, with some sort of investor protection. Such protection is to a lesser degree the same as mutual funds, which must include a minimum amount of diversification in various ways.

Holding companies can be involved in many sorts of financial operations that may involve a certain amount of risk and limited diversification, including investing in unlisted companies that have an uncertain market value. The purpose of mutual funds is first and foremost to invest in accordance to specified guidelines, including solely purchasing in listed securities with a known market value, that is supposed to ensure ease in selling those assets (usually referred to as liquidity) in markets were trade is frequent. Both entities generally fall under regulatory scrutiny but holding companies are held to a lesser degree than mutual funds, which are labelled as being financial companies and thus face more regulations and scrutiny by financial authorities. 
Another difference between the types of funds is the pricing mechanism, which is usually of minor importance but is important in this paper's discussion. Mutual funds are priced only once a day (after trading closes) according to their so-called net asset value (NAV). Each share is priced according to the combined market value of the assets within the fund (including cash) minus possible liabilities, divided by the number of shares outstanding. While the market value of holding companies follows a similar path, i.e., that the underlying net value of its holdings determines its price, differences between the calculated NAV (or intrinsic value) and the market value of the funds may occur. Because the shares of holding companies are listed, the price can fluctuate, reflecting changes in market sentiment.

While these issues contribute to the difference of the market value of investment holding companies and the worth of their underlying net assets, other issues come to play. Investment holding companies often trade at a discount in secondary markets as investors are able to diversify their holdings with lower transaction costs than the costs of control and management of a set of extant, standalone corporations (Vernimmen et al., 2009). There is, however, also the rare possibility that the market value of a holding company is higher than its (estimated) underlying net assets, known as a premium, as was the case with Exista, which we will better explain later in this paper.

Private Equity funds usually invest in unlisted start-up companies or companies in distress. Hedge funds are difficult to define but the general definition involves a great deal of leverage and willingness to take bets on all sorts of financial activities that may often involve betting on market prices going down, called in finance terms to take a short position. The hedge funds with the best returns year-in-year-out are sometimes called edge funds (the $h$ dropped) [Mallaby, (2010), p.6]. The distinction between the above categories is in some cases vague.

The governance of holding companies is inherently challenging, as they often fall under several regulatory regimes and the impact can be viewed that the regulators and governors each separately consider that another entity is responsible for the fiscal probity, financial strength and even control of the entity. The role of holding companies has received little attention in general. In the economics of developing economies, they are suggested as desirable as result of a combination of the lack of capital markets, the need for companies to be close to government and the shortage of managerial talent. For example, the role of Keiretsu in Japan (Grabowiecki, 2006), which were historically regarded as dysfunctional as seen by the reaction in the USA in the aftermath of the 1929 depression, and the Glass Steagall Act of 1932, which was to provide barriers to comprehensive financial holding companies (Galbraith, 1955/1997).

\section{Birth of Exista}

Iceland had practically no past history of banking in a normal business sense, with investment banking an unknown concept and commercial banking controlled by politics in most aspects within currency restrictions. This changed dramatically during the latter part of the 1990s following Iceland's participation in the European Economic Area in 1994, forcing the abolishment of currency restrictions and general liberalisation within the banking sector (Central Bank of Iceland, 2006). 
With the abolishment of a monopolised traditional banking system, competition began with interest rates no longer being politically regulated. The interest rate spread in Iceland's banking industry declined during the 1990s [Central Bank of Iceland, (2003), p.16]. Savings banks had for many years cooperated in various fields. Savings banks' traditional business was deposit taking and local lending. Then, as a consequence of the growth of the three banks and decreasing interest rate spreads within a liberalised banking environment, they were facing more competition and thus strengthened their relationship with Kaupthing Investment Bank (Kaupthing), which had been very successful and reaped great investment profits. The savings banks initially bought a $49 \%$ stake in Kaupthing in 1986, which was then a small boutique investment bank and buying the remaining 51\% stake in 1996 (Helgason, 2010). Kaupthing's operations increased dramatically over the next few years with its shares listed on the Icelandic stock exchange in 2000, its market value being 10 billion Icelandic krona (Morgunbladid, 2000), which totalled two-thirds of the combined total equity of the savings banks in Iceland year-end 2000 (SIC, 2014).

It was in this environment of rapid changes in Iceland's financial world that Exista was founded in 2001 as a holding company for seven savings banks, which became known as Exista-savings banks. Of the total 35.6\% share in Kaupthing owned by those savings banks, $11.1 \%$ were put into Exista. The following year, 2002, SPRON, the largest savings bank in Iceland, sold its entire $12.57 \%$ stake in Kaupthing to Kaupthing itself, which in turn sold the stake to Exista and accepted an ownership stake in Exista as payment, thus becoming a major owner of Exista with a $44 \%$ stake. In late December, 2002, a holding company, Bakkabraedur Holding bought a 55\% stake in Exista. Bakkabraedur Holding owned Bakkabraedur, a holding company that was the biggest owner of a fish packing and distributing company named Bakkavor. The owners of Bakkabraedur Holding were directors of Bakkavor. Its main banking associate, which a few years earlier were in charge of the initial public offering (IPO) of its shares, was Kaupthing (SIC, 2014). Bakkabraedur owned 29\% in Bakkavor with Kaupthing being the second biggest owner, with a 6.8\% stake in Bakkavor (Bakkavor Group, 2002; Kaupthing, 2002, 2004, 2007).

The initial asset of Exista was its purchase in Kaupthing with Bakkavor shares being added at a fervent pace in the coming years. Exista bought two additional companies in 2006. The first was the Icelandic Telecommunication Company, which was still a relatively small investment in Exista's investment portfolio. The second company was VIS insurance company, which owned Icelandic stocks with a total worth of 26.1 billion ISK. Two companies dominated the insurer's holdings; 21.2 billion ISK was in Kaupthing bank stock and 1.8 billion ISK was in Bakkavor stock (VIS, 2005). While the purchases of these two companies gained considerable media attention, the investments accounted for little of Exista's portfolio, which still remained mostly of Kaupthing bank and Bakkavor stock.

Exista was listed on the Icelandic stock exchange in September 2006. Just before this, it added a significant stake in Bakkavor, or $12 \%$ of the company, to its holdings. The number of shares in Bakkavor owned by Exista increased approximately $75 \%$. Shortly after Exista being listed, Sampo Group and Storebrand, both Nordic financial companies in the insurance industry, were bought with purchases beginning in the fall of 2006 for Sampo Group, but both announced early 2007. A 15.5\% stake was bought in Sampo Group and 8.7\% stake in Storebrand. Both these new companies were rumoured takeover targets of Kaupthing (Thorvaldsson, 2009). At year-end 2007, Exista owned a 19.98\% 
stake in Sampo Group, a 23.7\% stake in Kaupthing, a 39.63\% stake in Bakkavor, and an 8.69\% stake in Storebrand. The portfolio of Exista year-end 2007 shows that the stake in Sampo Group had become more than a third of its portfolio, but only due to Exista buying a large portion of the company. While the diversification was somewhat greater than it had been, Exista's assets were still concentrated in very few companies, with $31 \%$ of its stock assets (not total, which included also loans and was thus lower) in Kaupthing, 40\% in Sampo Group, 5\% in Storebrand and 10\% in Bakkavor.

Table 1 Percentage of Exista Holdings in Kaupthing and Bakkavor 2001-2007

\begin{tabular}{lccccccc}
\hline Icelandic krona & 2001 & 2002 & 2003 & 2004 & 2005 & 2006 & 2007 \\
\hline \% Kaupthing of total assets & $97 \%$ & $98 \%$ & $60 \%$ & $80 \%$ & $65 \%$ & $34 \%$ & $29 \%$ \\
$\%$ Bakkavor of total assets & $0 \%$ & $0 \%$ & $30 \%$ & $17 \%$ & $15 \%$ & $12 \%$ & $7 \%$ \\
$\% 2$ main owners total assets & $97 \%$ & $98 \%$ & $90 \%$ & $98 \%$ & $79 \%$ & $47 \%$ & $36 \%$ \\
\hline
\end{tabular}

Source: Exista (2001-2007)

Despite being initially a company that simply pooled together publicly traded shares in Kaupthing, with the additional main owners, Kaupthing and Bakkabradur Holding, contributing practically all of the funding into the fund with shares in their own companies, Exista was from its initial founding and throughout its entire existence highly leveraged (Exista, 2001-2007). In short, leveraged investments entail not merely buying assets with one's own money, but also financing such purchases with borrowed money. The higher the percentage of borrowed money, the more leverage takes place. If the money owed to finance the purchase of an asset, generally known as equity, is proportionally low, it can become quickly worthless if the underlying asset purchased falls in value.

Its equity ratio, which is the percentage of money financed by its own equity to buy assets, was on average 2001-2007 only 39\% (Exista, 2001-2007; and authors' calculations), meaning that investments within its balance sheet were on average financed more than $60 \%$ with money lent to the company.

Table 2 Exista equity ratio 2001-2007

\begin{tabular}{lcccc}
\hline $\begin{array}{l}\text { Icelandic } \\
\text { krona }\end{array}$ & 2001 & 2002 & 2003 & 2004 \\
\hline Total assets & 1.730 .145 .901 & 4.477 .410 .565 & 23.251 .591 .771 & 61.761 .549 .300 \\
Equity & 316.747 .296 & 1.286 .201 .737 & 11.798 .942 .072 & 26.341 .419 .730 \\
Equity ratio & $18 \%$ & $29 \%$ & $51 \%$ & $43 \%$ \\
\hline $\begin{array}{l}\text { Icelandic } \\
\text { krona }\end{array}$ & 2005 & 2006 & 2007 \\
\hline Total assets & & 415.821 .000 .000 & 2130.557 .600 .000 \\
Equity & 96.103 .537 .080 & 179.779 .000 .000 & 25.440 .000 \\
Equity ratio & $59 \%$ & $43 \%$ & $30 \%$ \\
\hline
\end{tabular}

Source: Exista (2001-2007) 
The development of this equity ratio might have been normal had it not been for the fact the underlying assets in Exista constantly rose in value for many years. This development had a great deal to do with the constant increase in assets. While the market value of shares owned by Exista rose with an astonishing regularity, the increase of asset value within the group was largely due to additional investments, constantly financed mostly with new loans. Even after having been listed as a public company in 2006, its total loans more than doubled in 2007, resulting in its equity ratio falling to record lows. In 2006 and 2007 , the percentage increase of assets financed with new loans was $67 \%$ and $88 \%$, respectively.

Table 3 Increase in loans and assets of Exista 2001-2007

\begin{tabular}{|c|c|c|c|c|}
\hline Icelandic krona & 2001 & 2002 & 2003 & 2004 \\
\hline $\begin{array}{l}\text { Annual increase } \\
\text { loans }\end{array}$ & & 1.777 .810 .223 & 8.261 .440 .871 & 23.967 .479 .871 \\
\hline $\begin{array}{l}\text { Annual increase } \\
\text { assets }\end{array}$ & & 2.747 .264 .664 & 18.774.181.206 & 38.509 .957 .529 \\
\hline $\begin{array}{l}\% \text { of increase assets } \\
\text { via loans }\end{array}$ & & $65 \%$ & $44 \%$ & $62 \%$ \\
\hline Icelandic krona & 2005 & 2006 & \multicolumn{2}{|c|}{2007} \\
\hline $\begin{array}{l}\text { Annual increase } \\
\text { loans }\end{array}$ & 30.258 .196 .448 & 170.363.673.982 & \multicolumn{2}{|c|}{278.490 .160 .000} \\
\hline $\begin{array}{l}\text { Annual increase } \\
\text { assets }\end{array}$ & 100.020.313.798 & 254.039.136.902 & \multicolumn{2}{|c|}{314.736 .600 .000} \\
\hline $\begin{array}{l}\% \text { of increase assets } \\
\text { via loans }\end{array}$ & $30 \%$ & $67 \%$ & \multicolumn{2}{|c|}{$88 \%$} \\
\hline
\end{tabular}

Source: Exista (2001-2007)

Jónsson (2009) argues those low equity ratios may be normal for production companies in the consumer staples field and thus providing constant revenues. The same did, however, not apply for investment companies buying listed shares, which could be rapidly worthless in a market downturn, which had already happened twice in the last 25 years. The report by Jónsson referred to an earlier interview in the same paper, Vidskiptablaðið (The Business Paper) in early 2006, where one of the Bakkabraedur owners and then current owner of that paper stated Exista's aim of investing in companies through leveraged buyouts.

\section{Who is the fairest of them all?}

Exista's profits were remarkable, demonstrating the magic of leverage when the market values of underlying shares rise in value. The investment's total assets year-end 2003 were less than five billion Icelandic krona, yet by year-end 2006 its cumulative profits since 2001 were 108 billion Icelandic kronas. 
Table 4 Exista net income 2001-2006

\begin{tabular}{lccc}
\hline Icelandic krona & 2001 & 2002 & 2003 \\
\hline Net profits & -197.525 .704 & -115.545 .559 & 6.129 .208 .386 \\
\hline Icelandic krona & 2004 & 2005 & 2006 \\
\hline Net profits & 15.068 .800 .400 & 50.314 .610 .334 & 37.410 .000 .000 \\
\hline
\end{tabular}

Source: Exista Annual Reports 2001-2006

Total profits from 2001-2006 were remarkable, with profits from a single investment company in 2005 just a shade less than the total profits of the three main Icelandic banks and the whole savings banks system in 2004. Icelandic investors paid little attention to the associated risks of such a structure and began assuming that further magic was down the road in Exista's market price. Once listed on the Icelandic stock exchange in 2006, the market value of Exista rose from 23 up to 40 Icelandic krona per share in ten months (OMX database), resembling Galbraith's (1955/1997) description of euphoric stock behaviour related to investment holding companies prior to the Great Crash in 1929. Its shares were traded most of the first year it was listed in 2006 and 2007 at a price-to-book $(\mathrm{P} / \mathrm{B})$ ratio, previously explained as the difference between the market price of its underlying assets and the NAV of those prices, hovering between 1.4 and 1.8 with an average of 1.5. This meant that investors were paying 140-180 ISK for net assets worth 100 ISK in a holding company that consisted mostly of a (very) few listed stocks investors could just as easily buy at the stock exchange. During that period, the equity ratio was usually below 50\%, meaning that for each 50 ISK of equity (assets owned by Exista) put into the holding company the market value was around three times the actual money contributed to the fund (50 ISK contributing to a market value of 140-180 ISK).

If one would have looked at the leverage of the underlying assets within Exista, the P/B ratio would have been even higher. All of Exista's holdings had a considerably high $\mathrm{P} / \mathrm{B}$ ratio, with the weighted average of the listed companies representing $80 \%$ of its total assets consisting of company shares, being 1.6 (2007 Annual Reports of Kaupthing, Sampo Group, 2007; Storebrand, 2007; and Bakkavor). Additionally, Exista had a considerable amount of goodwill in its books due to its purchase of VIS above its bookvalue. Combined, those calculations showed Exista having a 3.0 P/B value (authors' calculation). As shown, this euphoria surrounding Exista was to a great extent related to Exista using the fair value method in recording immense profits derived mostly from shares in Exista's two biggest interrelated owners.

In early 2007 Exista changed its accounting method. This is explained further on page 60 of Exista's 2007 annual report where it is stated that from the beginning of 2007 Exista's financial statements were to be prepared in euros, and while the strategic holdings of the company had previously been recorded at fair value, Sampo Group and Kaupthing were to be recorded using the equity method. This may have seemed prudent to observers but in reality this change of accounting method veiled drastic changes.

The equity ratio, as seen in Table 2, was publicly 30\%, with the Exista 2007 annual report stating on page 64 that: “The Group's equity ratio was $29.6 \%$ as of 31 December 2007." On the same page it is stated that the fair value of financial assets decreased $51 \%$ since the beginning of the year since Exista's share of Kaupthing is no longer entered at fair value, as in 2006, but is considered being an associate using the equity method. Since Exista bought a major share in Sampo Group the same year, it was also recorded using 
the equity method. As seen in the same annual report (101 and 102), it was in fact only $20 \%$, since the book value of the shares of Kaupthing and Sampo Group were no longer recorded at fair value, but had been frozen in early 2007 to a certain book value corresponding to the market value at that point. Kaupthing's and Sampo Group's share prices fell substantially that year, resulting in the market value of those two companies being actually 992 million euros lower than the stated book value in Exista's annual report. Exista announced record breaking profits for the year, or 574 billion euros (52.3 billion Icelandic krona), when in reality, using mark-to-market value method, the losses were 418 billion euros. While the difference of the book value was clearly detailed in the fine print of the report (the net income difference is not detectable without doing the math independently), the implications were hardly noticed, with no discussion in the Icelandic media. The equity value owned by Exista year-end 2007 was thus not in reality 2,369 million euros but $42 \%$ lower or 1,376 euros, resulting in a $20 \%$ equity ratio.

Table 5 Equity ratio of Exista year-end 2007

\begin{tabular}{lcccc}
\hline Million euros & $\begin{array}{c}\text { Kaupthing and } \\
\text { Sampo }\end{array}$ & Total assets & Equity & Equity ratio \\
\hline Equity value method & 4.738 & 8.011 & 2.369 & $29.6 \%$ \\
Fair value method & 3.745 & 7.018 & 1.376 & $19.6 \%$ \\
Difference & 993 & & & \\
\hline
\end{tabular}

Source: Exista (2007)

This meant that for all each 100 ISK asset invested, Exista owned less than $20 \%$ in those assets. The bulk of Exista's assets were in four companies that were publicly listed, Kaupthing, Bakkavor, Sampo Group and Storebrand.

Figure 1 Exista stock portfolio year-end 2007 (see online version for colours)

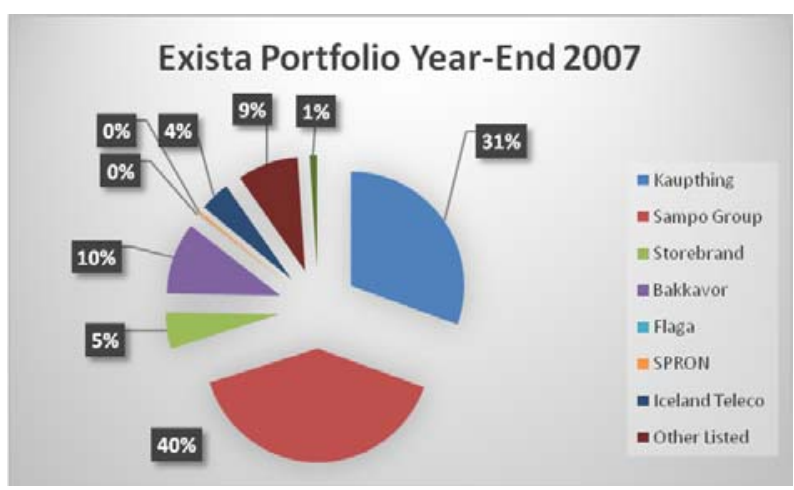

Source: Exista (2007)

At year-end 2007, the market value of those companies was about $85 \%$ of its stock holdings and close to two-thirds of Exista's total assets, meaning that a $30 \%$ (weighted average within Exista's portfolio) fall in share prices would have led to all of Exista's equity being wiped out. Investors would have had good reason to adjust their (euphoric) expectations of Exista year-end 2007, and adjusted the market value closer to its NAV. According to Exista's 2007 annual report, that was exactly the situation. It stated on page 
12 that "the price-to-book ratio (P/B) was 1.04", which was further emphasised by stating the same ratio under key figures on page 112. That was because the total market capitalisation of Exista year-end 2007 was 2,500 million euros and its recorded equity was 2,369 million euros. As shown in Table 4, the equity was in fact 1,376 million euros, meaning that the P/B ratio was not 1.04 but a staggering 1.8 for a company with no benefits related to mutual funds for proper diversification and leveraged to a degree that a relatively bad bear-market expected every few years would wipe out its equity.

\section{Type of fund}

While Exista was clearly an investment holding company, with all but $1.7 \%$ of its earnings directly related to its leveraged ownership in other companies, it still stated on page 60 in its 2007 annual report that it was developing "from an investment company into a financial services group”.

This raises the question of what type of company Exista really was. As explained above, Exista was a holding investment company but due to laws concerning its investment portfolio, which had well over half of its investments in financial companies (Kaupthing bank consisted year-end 2005 of approximately 60\%), it was forced by Iceland's Financial Supervisory Authority (FSA) to define itself as a financial company (SIC 2014). While that was a technical definition related to accounting standards, it meant that all the owners bar Bakkavor Holding were forced to deduct their ownership in Exista from their capital base in regards to Basel II calculations. Because of this, the owners of Exista had, in fact, repeatedly asked the Icelandic FSA permission to define the company as a holding investment company in order to enable the owners to gain more leeway in their lending abilities, but to no avail. Despite the owners' insistence during the previous years that Exista was an investment holding company, the message the Icelandic investment community received in 2006 when it was decided to float the company to new investors on the Icelandic stock exchange was that it was in fact a financial company. Shortly before the IPO took place in 2006, the two owners of Bakkabraedur Holding, one of whom was chairman of the board of Exista and Bakkavor, and the other one was also an Exista board member and CEO of Bakkavor, were interviewed by a major newspaper (Morgunbladid, 2006). In the beginning of the interview it is stated that Exista is a financial company with operations built upon three main pillars; insurance operations, property rental and investment banking. Later the chairman of the board 'admits' that the role model is the Berkshire Hathaway conglomerate. These statements could hardly be further from the truth. There were no operations within Exista; it was simply a holding investment company that had bought a few assets that were all related to Kaupthing. In fact, one could describe Exista at that point as not just an investment holding company but rather a large (leveraged) hedge fund with the risks being borne by the savings banks and Kaupthing, aided by the general public through Iceland's deposit insurance program, Bakkabradur Holding and then finally new owners who were both pension funds, and the general public in whole. Following the IPO, Exista became the most broadly owned company in Iceland, since Kaupthing distributed most its ownership in Exista to its shareholders.

Since it was so commonly owned after Kaupthing distributed part of its ownership in Exista to general investors, one could, on the surface, assume that the risks that many 
smaller investors took by investing in Kaupthing, commonly known as an aggressive bank, had their risk simply transferred into a holding company where the main components were holdings in Kaupthing, its main business associate or one of its main takeover targets. The reality was that many people owned Kaupthing shares because they had invested in its main mutual fund (this was before Chinese Walls were set up in Iceland between mutual fund companies and banks) with all its consumer protection and regulations regarding the minimisation of risk. Kaupthing decided unilaterally to 'merge' the mutual fund with Kaupthing, basically moving the mutual fund shares into Kaupthing's balance sheet against a share in the bank, meaning that those mutual fund owners became shareholders in a bank, which they then indirectly financed. Part of this 'investment' was again unilaterally transferred again in 2006 into Exista. While those owners of a mutual fund could trust, at least to a degree, that no regulations were being broken, that their ownership reflected the true NAV value, and that their investments were not being used within a leveraged operation, this changed once their ownership was transferred to Exista. Hence, those initial mutual fund owners had by now become investors in something like a hybrid of a private equity fund and a hedge fund, which had changed its accounting methods from fair value to equity.

The implication of the above from a governance perspective is that the main owners, along with other professionals, have created a financial services company that served to enhance the main owners with little regard for good governance on behalf of regular investors (Bryant et al., 2014). This was amply demonstrated when the share price of Bakkavor began falling in 2006 and Exista increased its stake in the company to 39\%, which the Chair of the Board of Exista and Bakkavor maintained was a good buying opportunity. This was close to the $40 \%$ limit by which Exista would have been by law required to acquire the whole company (Vidskiptablaðið, 2006).

Thus, when there is great liquidity in the system the perception is strong that this is the 'new normal' and such a situation will continue unabated. The change in shareholding is noteworthy as most of these changes were bought deals that did not go through traditional capital markets and were provided after the fact. We suggest that the regulators failed to appreciate that the risks to the increased risk to not just Exista but to the entire financial system that was ignorant through these changes. Furthermore, there were inherent conflicts of interest posed by a major shareholder able to gain access to easy debt to grow the Bakkavor enterprise and the potential off-shore risk as a consequence. Kaupthing was thus borrowing internationally while Exista funnelled cash from the savings banks to buy increased holdings in Kaupthing and Bakkavor and putting off the day of reckoning to both institutions, while ignoring the interest of minority shareholders.

It is not uncommon or unusual in developing economies that a holding company's structure has multiple business interests. Among examples are Tata and Reliance (India), Siemens (Germany), ABB (Switzerland), Hyundai and LG (South Korea), Fuji Heavy Industries and Sumitomo (Japan), Jardine Matheson and Swire (Hong Kong) and General Electric (US). Of these examples, only GE (2009, p.3) has a captive financial services enterprise and even here successive GE CEOs have stated that too much reliance on GE Financial is not in the best interests of the corporation. Thus what we have through Exista and the facilitating role played by the savings bank is essentially a flow through for both assets and financing with real risks that were not adequately captured by the market, largely through a combination of a highly complex and convoluted ownership structure, a total lack of transparency in the market and a failure of corporate governance. 
Because the regulator tended to look at form, not substance, being mainly lawyers, what mattered was the contract itself, not the intention of the parties. Iceland had five separate regulators, the Financial Authority, the Central Bank of Iceland (interest rates and inflation plus banks themselves, not relatedness), the Ministry of Finance in competition with the Ministry of Commercial Affairs (Jannari, 2009; SIC, 2010), and the Icelandic Stock Exchange. There was a lack of clarity regarding who does what and when and each kept information to themselves, therefore they felt the other authority was doing the work. It should also be pointed out that the Icelandic FSA during those years was constantly inadequately staffed, and as shown in this paper, Iceland also had no experience in investment banking only a decade before Exista was formed.

With the high P/B ratio of Exista, alarm bells should have begun ringing, especially since such a share price provides ample room for financial abuse, for example, as a tool to buy assets as if monopoly money was being used. This too provides further evidence of a failure of governance and a failure on the part of the regulators to examine the underlying economics. Thus, this implies that the existence of Exista was not only a hedge fund, sold to private investors as a solid financial holding company, but a hedge fund created by Kaupthing and Bakkabradur Holdings in order to generate apparent profits and the sense in the Icelandic community that even though there was a credit crunch, the Icelandic economy was insulated from these market shocks. Meanwhile, the main owners could entice other investors into Exista with high market multiples and have them finance their own investments by showing record mark-to-market profits, and once the liquidity within financial markets began evaporating in 2007, revert to equity method accounting standards, thus mostly concealing the losses when the tide in the stock markets turned.

\section{Conclusions}

Seldom, if ever, has a holding company such as Exista existed with such a large size compared to its headquarter nation's GDP, leverage, its irrational market price, its importance as an investment vehicle for the national pension fund system, and its lack of diversification and yet interrelatedness among the companies it invested in and its main owners, in addition to savings banks in Iceland. Its market value at one point reached the equivalent of 35\% of Iceland's GDP; the ratio for Apple's market value, today's most valuable company world-wide, compared to US's GDP is roughly 4\%. Apple computers sell hardware and software worldwide but Exista was a hedge fund.

Exista was advertised by its main owners as a financial services company. Yet practically all of its profits were derived from investment profits due to changes in stock market valuations of its holdings. This showed the appreciation of its equity, although it did not show the amount of leverage involved, largely because investors generally assumed the company was something like some sort of mutual fund or financial service company. 


\section{References}

Bakkavor Group (2002) Annual Report.

Benston, G.J. (2006) 'Fair-value accounting: a cautionary tale from Enron', Journal of Accounting and Public Policy, Vol. 25, pp.465-484.

Bryant, M.J., Sigurjonsson, T.O. and Mixa, W.M. (2014) 'Restoring trust in public institutions and the financial system', International Journal of Economics and Accounting, Vol. 5, No. 4, pp.306-319.

Central Bank of Iceland (2003) 2002 Annual Report, Chapter 2 [online] http://www.sedlabanki.is/uploads/files/arsk02-2.pdf (accessed 20 April 2013).

Central Bank of Iceland (2006) The Economy of Iceland [online] http://www.sedlabanki.is/lisalib/getfile.aspx?itemid=4689 (accessed 28 December 2008).

Epstein, R.A. and Henderson, M.T. (2009) Mark to Market: Can Accounting Rules Shake the Foundations of Capitalism, Working paper No. 45658, The Law School of the University of Chicago [online] http://www.law.uchicago.edu/Lawecon/index.html.

Exista (2001-2007) Annual Reports.

Galbraith, J.K. (1955/1997) The Great Crash 1929, Mariner Books, New York.

GE (2009) Annual Report.

Grabowiecki, J. (2006) Keiretsu Groups: Their Role in the Japanese Economy and a Reference Point (or a Paradigm) for Other Countries, Institute of Developing Economies, Japan External Trade Organization, Chiba.

Helgason, M.S. (2010) Íslenskt viðskiptalíf - breytingar og samspil við fjármálakerfið, Appendix 5 to SIC report [online] http://www.rna.is/media/skjol/RNAvefVidauki5.pdf (accessed 5 June 2013).

Jannari, K. (2009) Report on Banking Regulation and Supervision in Iceland: Past, Present and Future [online] http://eng.forsaetisraduneyti.is/media/frettir/KaarloJannari_2009.pdf (accessed 15 July 2009).

Jónsson, S.M. (2009) 'Spilaborg eignarhaldsfélaganna fallin’, Viðskiptablaðið, 20 September, pp.22-23.

Kaupthing (2002, 2004, 2007) Annual Reports.

Mallaby, S. (2011) More Money than God: Hedge Funds and the Making of a New Elite, Penguin Group, New York.

McLean, B. and Elkind, P. (2003) The Smartest Guys in the Room: The Amazing Rise and Scandalous Fall of Enron, Penguin Group, New York.

Morgunbladid (2000) 180 milljóna króna nýtt hlutafé á genginu 10,25 [online] http://www.mbl.is/greinasafn/grein/563110/ (accessed 23 October 2013).

Morgunbladid (2006) Nýr kostur í flórunni [online] http://www.mbl.is/greinasafn/grein/1102008/ (accessed 23 October 2013).

OMX Iceland: Database.

Sampo Group (2007) Annual Report.

Special Commission Pension Funds (2012) [online] http://ll.is/files/00_2012_Uttektarskyrsla/ Slides.pdf (accessed 24 October 2013).

Special Investigation Commission (SIC) (2010) Skýrsla rannsóknarnefndar Alpingis (Report of the Special Investigation Commission), Althingi, Reykjavik.

Special Investigation Commission (SIC) (2014) The Causes of the Fall of the Icelandic Savings Banks, Vol. 2, Chapter 10, Althingi, Reykjavik.

Storebrand (2007) Annual Report.

Thorvaldsson, A. (2009) Frozen Assets, John Wiley \& Sons, West Sussex. 
Vernimmen, P., Quiry, P., Dollochio, M., le Fur, Y. and Salvi, A. (2009) Corporate Finance: Theory and Practice, John Wiley \& Sons, West Sussex.

Vidskiptablaðið (2006) Exista nálgast yfirtökuskyldu í Bakkavör [online] http://www.vb.is/frettir/40503/ (accessed 18 November 2013).

VIS (2005) Annual Report [online] http://vis.is/media/1535/vis_frettir_2006-05.pdf (accessed 11 November 2013). 